\title{
Institutional Stakeholder-Driven Corporate Social Responsibility Understanding and Practices among Managers: The Case of Ghana's High-Risk Industries
}

\author{
Samuel Howard Quartey ${ }^{1} \&$ Edwina Howard Quartey ${ }^{2}$ \\ ${ }^{1}$ Department of Human Resource Management, Central Business School, Accra, Ghana \\ ${ }^{2}$ Registry, National Film \& Television Institute, Accra, Ghana \\ Correspondence: Samuel Howard Quartey, Department of HRM, Central Business School, P. O. Box DS, 2305, \\ Dansoman-Accra, Ghana. E-mail: squartey@central.edu.gh
}

Received: April 11, 2015

Accepted: May 4, 2015

Online Published: June 20, 2015

doi:10.5539/ijbm.v10n7p145

URL: http://dx.doi.org/10.5539/ijbm.v10n7p145

\begin{abstract}
This paper explores high-risk industries to understand how institutional stakeholders drive corporate social responsibility understanding and practices. The high-risk industries in Ghana were investigated to understand how their managers' corporate social responsibility understanding and practices have been influenced by their institutional stakeholders. A qualitative study using multiple-embedded case study approach was adopted. Thirty (30) managers were sampled, contacted and interviewed. Data was analysed using qualitative content analysis. From the findings, institutional stakeholders largely influence managers' understanding and corporate social responsibility practices. Another finding indicates that the high-risk industries and their managers define corporate social responsibility as meeting the expectations of their internal and external institutional stakeholders. Employees and shareholders are the key institutional stakeholders regarding corporate social responsibility in the high-risk industries. Core among the corporate social responsibility practices in the high-risk industries are profitmaking and environmentalism. Going forward, this paper argues that managers' corporate social responsibility understanding and practices should rather be informed by industry strategy and not largely by institutional stakeholders' demands.
\end{abstract}

Keywords: corporate social responsibility, high-risk industries, institutional stakeholders, managers, Ghana

\section{Introduction}

This paper explores the high-risk industries to understand how institutional stakeholders influence managers' corporate social responsibility (CSR) understanding and practices. Corporate social responsibility means the duty a corporation has to create wealth by using means that avoid harm but protect and enhance societal assets (Steiner \& Steiner, 2000). A high-risk industry may be firms that potentially cause harm or posse threat to the internal and external business environments (Reason, 1997). According to Okun, Lentz, Schulte and Stayner (2001), the oil and gas, forestry, aviation, construction, nuclear power, shipping and manufacturing industries are some of the well-known high-risk industries. These industries are high-risk because their operations can threaten the health and safety of people, communities, environment and the society (Reason, 1997). Thus, high-risk industries provide enough reason to be investigated in order to provide insights into how their CSR knowledge influences CSR practices given their industry-institutional contexts. Although it is expected that CSR practices should conform to industry-specific institutional pressures, however, this may not always be the case for developing country industries and managers. As acknowledged by Pedersen (2010), how managers' perceive and understand CSR determines the nature of CSR practices and performance in industries.

However, despite the high expectations for high-risk industries in Ghana to be socially, economically and ethically responsible, little is known about how their managers' knowledge of CSR influences CSR practices. Thus, more understanding is urgently needed to explain how the institutional pressures on high-risk industries influence the way they conceptualise and practice CSR. Besides the increasing institutional demands, high-risk industries and their managers may not have the complete understanding of CSR despite the pressure from their institutional environments to do so (Fafalioua, Lekakoub, \& Theotokas, 2006). Because responding to institutional CSR pressures are necessary to improve and strengthen legitimacy and acceptance for high-risk 
industries in the wider stakeholder community (Brammer, Jackson, \& Matten, 2012).

More specifically, studies on CSR in the Ghanaian context remain limited, especially those that examines CSR from the viewpoints of managers of high-risk industries. Nonetheless, existing studies have largely focused attention on the extractive industry (Hilson, 2007; Dashwood \& Puplampu, 2010; Yankson, 2010; Hilson, 2012), construction industry (Lichtenstein, Badu, Owusu-Manu, Edwards, \& Holt, 2012), high-impact industry sectors (Abugre, 2014), banking and financial industry (Ofori \& Hinson, 2007b; Hinson, Boateng, \& Madichie, 2010; Hinson, 2011), the telecommunication industry (Hinson \& Kodua, 2012; Mahmoud \& Hinson, 2012), local and foreign firms (Kuada \& Hinson, 2012). Others have also examined CSR application at the national level (Amponsah-Tawiah \& Dartey-Baah, 2011a; 2011b). These studies have explored the exploitation of CSR as a marketing tool. They have further examined the industry databases to understand how CSR is reported. They have also argued for the localisation of CSR in African countries including Ghana. Most of these studies have compared and contrasted CSR practices of local firms and foreign firms. Others have examined the organisational characteristics that influence CSR adoption and adaptation. Some have examined the managerial role in the practice of CSR in Ghana, but practically no research has been done in the high-risk industries to understand how their managers' knowledge of CSR shapes CSR practices. More importantly, this paper argues that managers understanding and practices of CSR should conform to certain institutional and environmental pressures. These pressures and demands may come from institutional stakeholders' such as employees, customers, shareholders, community, government agencies, creditors, suppliers and the society. Because an industry's institutional environment plays key role in shaping managerial understanding towards social behaviors including CSR practices.

This paper fills part of this research gap in our understanding of how CSR is understood by managers of high-risk industries, and how this understanding influences CSR practices. Essentially, this paper seeks to develop our understanding of how the meaning and practices of CSR are shaped within an industry's institutional context. In so doing, this paper addresses a broad research question of how institutional stakeholders influence managers understanding of CSR towards CSR practices in the high-risk industries. The first section of this paper provides the theoretical background of the study. It further provides brief context of high-risk industries in Ghana, and thus reviews literature on CSR practices in high-risk industries. The second section provides a brief description of the empirical process. The third section presents the findings. The fourth section discusses the main findings. The final section concludes the paper and highlights the theoretical and managerial implications.

\subsection{The Background of the High-Risk Industries in Ghana}

The shipping and manufacturing industries are considered as high-risk industries in Ghana. As their operations have several implications for the health, safety and environment of their employees (Quartey \& Puplampu, 2012). The Ghanaian shipping industry is largely situated in the two major seaport cities namely: Tema and Takoradi. As a multinational industry, the shipping companies are mainly from North America, Far East, Europe and other parts of Africa (Pedersen, 2003). The shipping firms are vertically integrated with multinational companies dominating various sectors (Pedersen, 2001). The sectors of this industry include freight-forwarding, container and logistics transports (Pedersen, 2001). They operate general cargo, Ro-Ro, container multi-purpose, cell container, bulk container and tanker vessels (GMA, 2011). This industry is regulated by institutional agencies such as Ghana Shippers Council, Ghana Port and Harbours Authority and Ghana Maritime Authority. These institutional agencies are mainly responsible for promoting social, economic, environmental and ethical practices through compliance within the shipping industry (GSC, 1997).

On the other hand, Ghana's manufacturing industry is also located in big cities such as Accra, Tema, Takoradi and Kumasi. This industry has seen tremendous industrial change due to the introduction and implementation of Economic Recovery Programme (ERP), known as the Structural Adjustment Program (SAP) in 1983 (Amoako-Gyampa \& Boye, 2001). This industry is relatively weak with low investments. The industry is also dominated by foreign manufacturing firms because local firms easily exist due to high competition (Frazer, 2005). The sectors of this industry include pharmaceuticals, metallurgy, agribusiness and food processing, beverage, textiles and garments, wood and wood products, cement, chemicals, plastics and rubber (Sutton \& Kpentey, 2012). These sectors are largely SMEs with less state-ownership but more foreign ownership (Soderbom \& Teal, 2004).

\section{Literature Review}

\subsection{Institutional Theory}

Institutional theory emphasises that firms are under pressure to adapt to and be consistent with their institutional environments (Scot, 2001). The idea is that firms can be legitimate and accepted members of a business 
environment when they learn to conform to these institutional pressures. This implies that firms with time may come to behave similarly as a sign of stability and conformity to institutional pressures and expectations. Fundamental to this theory is the role of institutions. Institutions are not only formal organisations of government and corporations but they could also mean internal and external rules, values, incentives and norms that presses firms to adopt and adapt to institutional demands (Jackson, 2010). These institutions are important to understand any form of social behaviours as either reinforcement or punishments. Because it has been argued that institutions are useful to demand and reinforce appropriate social behaviours and organisational practices (Scot, 1995). The institutional perspective has influenced many scholarly works. Recently, this perspective has been applied to explain why different firms tend to understand and practice CSR differently (Campbell, 2007; Matten \& Moon, 2008). Studies examining CSR in developing country contexts have also used this theory to understand the similarities and differences in CSR practices (Amran \& Devi, 2007; Jamali \& Mirshak, 2007; Jamali \& Neville, 2011). However, none of these studies have examined CSR understanding and practices of high-risk industries using this theory. This paper applies the institutional perspective to develop our knowledge of how institutional stakeholders influence CSR understanding of managers towards CSR practices in the high-risk industries. This paper argues that for high-risk industries and their managers to understand and demonstrate appropriate corporate social behaviours require an effective institutional presence. Because institutions are important to ensure that appropriate structures and processes are established by high-risk industries to demonstrate stable patterns of corporate social behaviours.

Established institutions are able to define rights and responsibilities, and further shape the identities of social actors to demand social responsibilities (Jackson, 2010). For example, there are institutional stakeholders and related pressures that are supposed to influence the social behaviours of high-risk industries in Ghana. These institutions are expected to define their rights and responsibilities and further shape the behaviours of high-risk industries. Nonetheless, whether these institutions are effective or not can be seen in the way industries engage with corporate social behaviours. These pressures are necessary if high-risk industries are to acquire any recognition and social legitimacy from their wider stakeholder community. Through their pressures and demands, these institutional stakeholders such as employees, shareholders, community, government or regulatory agencies, suppliers, customers, creditors and society can influence the understanding and practices of CSR in the high-risk industries.

DiMaggio and Powell (1983) argued that for firms to gain legitimacy and acceptance in their business environments requires appropriate responses to these pressures called "isomorphism". To do this, high-risk industries in Ghana can imitate other successful firms, respond to imposed pressures and regulations from powerful and legitimate body, and adopt industry practices suggested by professional and accredited industry associations. Also, the institutional pressures clearly specify industries social behavioural requisites for conformity. Additionally, institutional perspective may offer an opportunity to understand how local institutions shape managers understanding of what constitute their industries social behavioural expectations. Even if high-risk industries and their managers' are foreign to their local industry environments, they can imitate, succumb to pressures from regulatory bodies, or even better be advised by industry and professional bodies to exhibit socially desirable behaviours. Thus, CSR practices of high-risk industries can be influenced partly or fully by these institutional pressures and expectations. For some of the high-risk industries, CSR may be driven by the need to comply strictly with national, supranational and international regulations and laws (Selkou \& Roe, 2004). These are example of institutions that are more likely to influence CSR understanding and practices by managers of any high-risk industries. This paper seeks to explain CSR understanding and practices by drawing from the perspectives of institutional theory.

\subsection{Understanding Corporate Social Responsibility (CSR)}

Over the past three decades, the meaning of CSR has been more confusing than ever. Visser (2008) described CSR as the formal and informal ways in which businesses make contribution to improve the governance, social, ethical, labour and environmental conditions of the countries in which they operate, while remaining sensitive to prevailing religious, historical and cultural contexts. This understanding takes a multinational perspective but it is useful for high-risk industries and their managers that operate in foreign countries. Amaeshi et al. (2006) have conceptualised CSR as a localised and socially embedded concept whose ideas, perceptions, issues and modes of practice are true reflection of an organisation's reaction to its socio-economic environment. This means that high-risk industries responses to CSR can be understood by their underlying business philosophies and operating environments. Halme and Laurila (2009) argued that CSR is when an organisation is able to effectively combine responsibilities toward internal and external stakeholders with its core business operations. This requires high-risk industries to consider how the expectations of internal stakeholders and external stakeholders fit within 
their business activities. To achieve this, Waddock and Graves (1997) have advised that the treatment of a firm's internal and external stakeholders must be well-operationalised in its day-to-day business operations to avoid irresponsibility. Wartick and Wood (1998) further sum-up what CSR really means to organisations. They said that CSR implies the need for organisations to mitigate problems they cause, follow laws, behave ethically, perform economically and meet social expectations of their societies. Wartick and Wood (1998) in their definition addressed the social, economic, legal and philanthropic responsibilities of any business organisation as proposed by Carroll's (1991).

\subsection{Corporate Social Responsibility Practices in the High-Risk Industries}

As argued by Reason (1997), the shipping and manufacturing industries can be classified as high-risk industries in developing and developed countries. Manufacturing firms have many CSR practices. Huang and Kung (2011) found that managers of the manufacturing industries tend to be conscious of environmental awareness and environmental performance. A number of studies have also shown that manufacturing managers address environmental issues by investing in green programs (Williamson, Lynch-Wood, \& Ramsay, 2006; Panwar \& Hansen, 2009). Increasing profitability towards financial performance is another social responsibility of managers within the manufacturing industries. Heinze, Sibary, and Sikula (2010) found that manufacturing firms and their managers consider profitability as CSR practices. As a result these industries choose and invest in social projects and programs that can add value to their investment portfolios and shares. Thus the need to perform financially often underpins their social behaviours (Torugsa, O'Donohue, \& Hecker, 2011). Diller (1999) found that many manufacturing firms perceive the existence of labour-related code of conducts and adherence to labour standards as part of their CSR practices. To pursue this, most manufacturing firms formulate and implement labour-related codes of conducts to address issues such as child labour, forced labour, discrimination, freedom of association, employee health and safety and welfare (Yu, 2008). Also, Metaxas and Tsavdaridou (2012) found that some manufacturing firms invest in CSR activities such as environmentalism, training and development, occupational health and safety, community involvements, philanthropic donations and sponsorships.

The shipping industry has been recognised as an industry with several CSR practices. Poulovassilis and Meidanis (2013) found that shipping firms have made several commitments to improve CSR practices for their internal and external stakeholders. As a high-risk industry, shipping firms have strict regulatory regimes that have renewed their attention towards CSR commitments (European Commission Communication, 2004). As found by Roe (2008a), the CSR practices of the shipping industry are often geared towards their operational issues such as the environment, security, safety and probability. To meet these operational issues, most shippers provide appropriate working environment for employees, vessel and the environment in addition to medical and health insurance (McSweeney, Craig, \& Tomlinson, 2013). A study has found that shipping companies believe solving internal and external stakeholder issues such as health and safety, codes of conducts, environmental management, community relations, human rights, employee life-long learning programs, social responsible investments, ethnic minorities, philanthropic donations and charity customer relations constitute CSR practices (Fafalioua, et al., 2006). These CSR programs are often influenced by the understanding that employees are potential candidates to risks and hazards in the shipping industry (Havold \& Nesset, 2009).

In addition, some shipping firms consider intensive and appropriate health and safety training and education as a way to protect seafarers' health, safety and security (Horck, 2004; Barsan, Surugiu, \& Dragomir, 2012). These training and educational programs are often intended to create safety awareness and competence among seafarers. Due to the risky nature of this industry, seafarers' welfare at sea has been a major CSR priority for shippers. Ellis and Sampson (2013) found that the shipping industry provide good resting periods, descent accommodation and recreational facilities as part of their CSR. A study has also found that dominant on the CSR agenda of shipping companies are health, safety and environment (Acciaro, 2012). This is because shippers are mostly compelled to conform to strict national, supranational and international regulations on maritime safety, health and environment (Selkou \& Roe, 2004). For the shipping industry, due to the huge investments they consider profitability as next to health, safety and environment ( $\mathrm{Lu}, \mathrm{Lin}, \& \mathrm{Tu}, 2009)$. Moreover, managers often pursue profitability because of agency-related problems (Abor \& Biekpe, 2007).

\section{Method}

\subsection{Sampling Procedure and Participant Characteristics}

A qualitative study using a multiple-embedded case study approach was adopted to explore how institutional stakeholders influence managers CSR understanding and practices in the high-risk industries. This approach was used because it was able to draw empirical evidences from multiple cases to provide deeper insights into the 
social phenomenon (Creswell, 2007). Consequently, six (6) multiple-embedded cases representing six (6) firms comprising of three (3) each from the shipping and manufacturing industries were sampled. The three (3) shipping companies were randomly selected from the database of more than fifteen (15) registered shipping companies as drawn by the Ghana Maritime Authority (2011). Also, the three (3) manufacturing companies were randomly selected from thirteen (13) listed manufacturing firms on the Ghana Club 100 as drawn by the Ghana Investment Promotion Centre (GIPC, 2012). For the sake of confidentiality and anonymity, the names of these firms were kept private. Thirty (30) managers from six (6) firms in the shipping and manufacturing industries were purposively sampled. These managers were contacted and agreed to participate in the study. The managerial positions of these managers comprised: corporate affairs managers; human resource managers; health, environment and safety managers; production managers; sales and marketing managers; finance managers; and operations managers. As can be seen, these managers were directly involved in different aspects of corporate social responsibility. However, it must be indicated here that, this paper sought to understand how institutional stakeholders influence managers CSR understanding and practices at the industry-level of analysis by interviewing only managers who were directly involved in CSR activities.

\subsection{Data Collection Procedure}

Data was collected using semi-structured interviews. This procedure of data collection was appropriate because it allowed flexibility for the managers to raise and discuss matters of great importance to them (Denzin \& Lincoln, 2005). Prior to the interviews, the consent of each manager was sought. Those who agreed to participate were interviewed. Interviews were conducted face-to-face with all the managers. The interviews lasted between 40-45 minutes. For the sake of consistency, an interview schedule was developed to guide the researcher. The research questions addressed issues that related to: managers CSR understanding and practices based on the pressure from their institutional stakeholders. Interviews were digitally-recorded. The data collection period lasted for three (3) months, because many of the managers were busy. Internal validity was ensured by addressing observed discrepancies in the data and discussing these discrepancies with respective managers for clarifications. Reliability was also ensured by providing detailed accounts of the data collection procedures for the sake of replication, as suggested by Berg and Lune (2004).

\subsection{Data Analysis Procedure}

The data was analysed using qualitative content analysis approach which has been argued as the most effective way to ensure comprehensiveness of text material (Miles \& Huberman, 1994). These small-scale interviews were not analysed using computer-based content analysis approach, as this can reduce the originality of the text material (Bazeley, 2007). As a consequence, interviews were manually transcribed and coded. With specific reference to the theoretical and empirical perspectives, a good category system emerged from the data, as the researcher found and generated the category system as recommended by Mayring (2003). The units of analysis were words, phrases, sentences and paragraphs relevant to this study (Denzin \& Lincoln, 2005).

\section{Results}

This paper presents the key findings using relevant themes and quotes that emerged out of the data analysis. This style of presenting the findings is able to keep the originality of the text materials, as argued by Burnard (2004). Following Miles and Huberman (1994), content analysis technique was used to analyse the interviews so as to identify patterns in the data. This was necessary to infer from the interviews what CSR meant to the managers, and also to identify current CSR practices as influenced by institutional stakeholders of the high-risk industries. Below is the presentation of the key findings under the major themes and verbatim quotes.

\subsection{The Understanding of CSR by Managers in the High-Risk Industries}

The interviews explored how managers' understanding of CSR was pressured by their institutional stakeholders. Corporate social responsibility in these industries means addressing internal and external stakeholder issues. Their understanding of CSR is closely related to the idea of institutional stakeholders. Because most of the managers thought industry stakeholders were more important to direct their CSR understanding. When asked to indicate their understanding of CSR, almost all of the managers interviewed pointed out that, meeting the expectations of their internal and external stakeholders is critical to their understanding of CSR. These managers commented that:

For us, CSR means meeting the expectations of our industries' internal and external stakeholders.

When asked to comment on why they think this understanding was good for them to do more CSR, most of these managers were of the view that because they can achieve their ultimate goal when these institutional stakeholders are satisfied. Thus, managers aligned meeting the expectations of these stakeholders to goal 
achievement. Again, like many industries, these high-risk industries had so many institutional stakeholders, but not all of them were actually directing their understanding of CSR through their demands and expectations. Given the nature of their industries as risky, hazardous and capital intensive, managers were of the view that meeting pressures from institutional stakeholders. They categorically indicated that their institutional stakeholders are employees, customers, shareholders, customers, community; government and the environment often dominate their understanding of CSR. Practically, doing what these stakeholders want was enough to determine their CSR understanding.

These managers said that:

We need to work hard to meet the expectations of our key stakeholders like employees, shareholders, customers, customers, community, government and the environment. We may not meet the expectations of everyone but for these stakeholders we try always to do that.

More specifically, it is expected that every organisation pursue CSR that addresses the concerns of all stakeholders. However, when asked to tell which of these stakeholders were instrumental or key to their understanding of CSR, the managers intimated that employees and shareholders still remain the favourite among these stakeholders. According to the managers, their firms' responsibilities towards employees and shareholders are crucial to the industry. This was confirmed by the managers. As most of the managers put it:

Every business is expected to have a lot of responsibilities towards many stakeholders. For us, it is our employees and shareholders. In the first place, without these stakeholders there wouldn't be any business. After these people then we look at the other ones. Not that we don't respect the expectations of the others, but these two matter more.

\subsection{Corporate Social Responsibility Practices in the High-Risk Industries}

The interviews also explored the CSR practices currently available in the industry. In particular, this paper sought to understand how the expectations of the industry's institutional stakeholders influence CSR practices. As a result, managers were asked during the interviews to indicate the CSR practices currently available given their institutional stakeholders' demands. Below is the thematic analysis of the CSR practices that were mentioned by the managers during the interviews.

\subsubsection{Employees' Health and Safety}

The nature of the high-risk industries is widely described as risky and dangerous for its workers. As a result, firms operating within these industries are expected to receive appropriate health and safety precautions and programs. When asked to show the nature of health and safety programs available to employees, managers first subscribed to this philosophy by saying that, their firms try as much as possible to provide enough protection for employees' health and safety. During the interviews, a group of managers revealed that, given their industry situations and institutional pressures to be socially responsible, they have been committed to providing medical and health insurance for employees. In addition, employees' families are also given similar medical and health insurance. These health and safety packages are provided for every employee. Managers further revealed through the interviews that, their firms provide full medical and health insurance without any limit as long as the employees are injured and their spouses and children are sick. Some of the managers said that:

We have a medical and health insurance for every employee, whether you are a man or woman. You can bring your wife and children without paying for anything. It covers the employees, their children and the spouses. There is no ceiling. We cover the medical bills for employees and their families.

Regarding employees safety, managers were of the view that, safety is better when aligned with enough safety equipment. As a result, employees are given the needed safety tools to do their jobs. These managers reported that these safety kits and equipment are given to employees in order to safeguard their health and safety on the job. When asked to comment on employees' safety practices, some of the managers commented that:

Working in this kind of industry is admittedly risky and hazardous. That is why we provide our employees the needed safety kits and equipment. This is necessary to protect employees from jeopardizing their safety, wellbeing and health.

During the interview discussions, managers also reported that, their firms do sometimes experience safety accidents involving employees. The managers explained that because employees work with huge machines and work in risky environment, they need to be well-protected from risks, harms and hazards. When asked to comment on employees' safety issues, some of the managers indicated that: 
Look at our huge machines and cranes, our staff need something to protect themselves from falling things or objects; and from falling down before someone dies. Although few, some staff have lost part of their body like fingers, hands and leg before. We need try to curb these accidents as much as possible.

\subsubsection{Corporate Donations and Scholarships}

Corporate philanthropy is another area of CSR that these industries provide to communities school children and schools. According to the managers, their firms do well by giving back to the society, schools and communities. Managers said that they occasionally make donations and give sponsorships to needy but brilliant school children. This aspect of CSR was further extended to communities during disasters.

Some of the managers said that:

We must give back to society because whatever we do in the society, we take something from it so we must give back. For example we give donations and sponsor needy but brilliant school children. Communities also receive our supports particularly during disasters.

Moreover, it turned out during the interview discussions that managers who support corporate philanthropy are religious and "Christianised". A manager commented that:

Our top managers are very religious. These managers believe in doing "good" because they are Christians who go to church. Some of the managers even say "God will replace the good we do" so we give back to the society and community when we can.

\subsubsection{Employees' Welfare Programs}

Managers also revealed that their firms provide welfare programs for employees. Managers acknowledged that, as part of their social responsibilities their firms provide welfare packages to employees'. Managers further mentioned during the interviews that, employees' welfare packages include subsidised cafeteria or lunch, free transportation, soft loans and bereavement assistance programs. Some of the managers cited that:

We support employee welfare by giving our staff assistance during bereavement or funeral, offer free transportation home, soft loans during financial crisis, and also reduce canteen prices for lunch.

\subsubsection{Training and Development Programs}

As part of their CSR, managers also said that their firms provide training and development programs for employees. This provision was intended to help employees manage risk and hazards at the workplace. When asked, managers said that:

To help staff manage risks and hazards on site, we offer them health and safety training programs.

Some of the managers further revealed that the employee development aspect of the training are often geared towards supervisors or managers. However, it was explained that managers and supervisors need the development programs to supervise staff well on sites. Few managers commented that:

For supervisors to supervise well, they also receive development programs.

\subsubsection{Environmentalism}

It came across during the interview discussions that, these firms are concerned about the environment. When asked further about the environment, a group of managers indicated that as part of their firms' social responsibility. Managers commented that:

Protecting the environment is a core aspect of our social responsibilities and business objectives.

The managers revealed that because their firms' operating environments are often perceived as environmentally unfriendly, they try to manage their environment issues well. Managers revealed that, their firms do this by adhering to the national laws, directives and policies on environment. To have a positive standing with state institutional agencies on the environment, they have actually put in place environmental management plan as demanded by the Environmental Protection Agency (EPA). The EPA is a national regulatory institution for monitoring and ensuring sound environmental practices in the country. Some of the managers said that:

If you want the environmental agency to be your friend, then you have to follow their policies, laws and regulations. We work in an industry where everybody thinks it is environmentally unfriendly. To show our commitments towards protecting the environment, we have a three year environmental management plan with EPA which is renewable. 


\subsubsection{Paying Taxes}

During the interviews, a handful of the managers said that paying taxes is a corporate social responsibility. To fulfil statutory laws and requirements, these managers indicated that they encourage their firms to always pay their taxes on time. When asked the reason, managers were of the view that, paying taxes is necessary to avoid penalties from state institutions or law enforcement agencies responsible for collecting taxes. The managers indicated that:

We pay our taxes to the state institutions or law enforcement agencies as part of our CSR. We try to do this on time to avoid penalties and embarrassment from these regulatory agencies or tax offices from the government.

\subsubsection{Profitability}

Making profit was revealed as another core as aspect of the firms' social responsibility. The managers interviewed remarked that their shareholders, creditors and employees expectations require them to make more profits. As managers they are expected especially by the shareholders to make profit to keep their shareholder-agency relationship. Actually, making profit was referred to as "corporate goal". Managers opined that:

One of our core corporate goals is to make profit. The expectations of our shareholders, creditors and even employees put a lot of pressure on us managers to make profit. Even worse, you can lose shareholder-agency relations as a manager if you don't find ways to make profit. We are here to make profit.

\section{Discussion}

This paper reveals that managers of the high-risk industries define corporate social responsibility as meeting their internal and external institutional stakeholder expectations. By institutional stakeholders, the managers mentioned employees, shareholders, creditors, community, government or state regulatory agencies and the society. Similar understanding of CSR has been argued by Halme and Laurila (2009). According to them, CSR can be explained as mainstreaming internal and external stakeholders' demands into an organisation's core business. Consistent with this finding, high-risk industries often perceive CSR as addressing internal and external stakeholder issues (Fafalioua et al., 2006). However, what has not been observed in current literature is how institutional stakeholders can direct the conceptualisations of CSR by industry managers. According to the findings, many of the high-risk industries and their managers perceive CSR as what their institutional stakeholders demand. Moreover, whether this understanding of CSR as driven by institutional stakeholder is strategic has not been fully addressed in literature. For the managers, satisfying institutional stakeholders' demands and pressures often guide and frame their understanding of CSR. Because the pressure from firm, industry and state level institutional stakeholders can have strong influence on how managers define CSR. From the interview, managers were of the view that these institutional stakeholders put a lot of pressure on them to practice CSR.

This paper finds that employees and shareholders were the primary institutional stakeholders of the high-risk industries. Because from the interviews the managers indicated that employees and shareholders were their major concern. Concerning employees, the reason may be that they are potentially exposed to high-levels of risks, hazards and accidents (Havold \& Nesset, 2009). Regarding shareholders, Carroll (1991) argued that managers and owners are often pressured to make profit as part of their social responsibilities. However, for the managers, they may be pressured by the need to protect and maximize shareholders value and shares to secure better agency relationship (Abor \& Biekpe, 2007).

This paper further finds that the CSR practices in the high-risk industries were driven by the need to meet the expectations of institutional stakeholders. Therefore, managers tailored their CSR towards addressing internal and external stakeholder issues in the industries. The CSR understanding by the managers drove towards certain kinds of CSR practices such as employee health and safety, corporate donations and scholarship, employee welfare programs, training and development, environmentalism, payment of taxes and profitmaking. Managers revealed that these are the CSR practices currently available to their stakeholders. However, managers mentioned that among these social responsibilities, profitmaking and environmentalism were considered core to the industries business operations.

Selkou and Roe (2004) explained that due to national, supranational and international legislative pressures, most high-risk industries have decided to adopt and practice environmental management or inculcate green culture. According to these findings, these industries are seemingly pressured by a national institutional agency like the Environmental Protection Agency (EPA) to adhere and uphold directives, policies and regulations governing environmental management. This finding supports previous studies which found that these high-risk industries 
negatively affect the environment through their activities and are currently committing to put in place measures to address these environmental issues (Williamson et al., 2006; Acciaro, 2012). Due to this negative reputation and the need to build good reputation and image, many high-risk industries are currently working hard towards mainstreaming environmentalism into their core business operations (Huang \& Kung, 2010).

Furthermore, this paper also shows that corporate philanthropy is driven by religious reasons. Mangers said that their firms' decision to practice philanthropy is often driven by the religious philosophies of the managers. This finding is inconsistent with a previous study that corporate philanthropy is driven by the need to build strong public and community relations (Metaxas \& Tsavdaridou, 2012). Consequently, managers' religious values and beliefs are central to CSR understanding and practices. Additionally, profit making intentions of the managers were considered another core goal of the industries. As a social responsibility, profitability was regarded as core consideration in the very existence of the industries. As already discussed, the reason is that managers want to keep agency relationship, meet stakeholder demands and perhaps pay taxes. These reasons have been put forward and discussed by past studies ( $\mathrm{Lu}$ et al., 2009; Torugsa et al., 2011). This paper observes that, the managers CSR understanding and practices were driven by their institutional stakeholders' expectations.

\section{Conclusion}

This paper makes a number of theoretical and managerial contributions. The theoretical contributions from this paper are in three aspects. First, institutional theory has provided insights into how institutional stakeholders drive the understanding and practices of CSR in high-risk industries. We now understand that, the gap between understanding and practicing CSR in high-risk industries is filled and influenced by the expectations of institutional stakeholders. Second, this paper adds to existing literature by discovering that industry's understanding of CSR can be driven by the pressures from its institutional stakeholders. As a result, the paper has added to our qualitative understanding of how the Ghanaian institutional stakeholders influence the nature and content of CSR in the high-risk industries. Third, this paper has demonstrated that the institutional environment of industries has a strong impetus for CSR understanding and practices. In that, managers seek to always fulfil their fiduciary obligations towards primary stakeholders before anything else. Such an understanding from managers may dominate the thinking and practices of CSR in high-risk industries.

The managerial contributions from this paper can be seen in four aspects. First, the high-risk industries and their managers require a strategic understanding of CSR through a comprehensive dialogue between themselves and their institutional stakeholders. Simply conforming to the pressures from institutional stakeholders may not be enough to make strategic CSR decisions and commitments. Because it can be observed from the findings that, the CSR practices of the high-risk industries are institutionally-oriented and not strategic. Second, to build long-lasting relationships and gain legitimacy and acceptance from the wider institutional stakeholder community requires managers to widen their CSR coverage to include every stakeholder and not only employees and shareholders. Third, the high-risk industries and their managers should mainstream their CSR commitments into their core industry business and strategy. Four, mainstreaming the internal and external stakeholder expectations into their core businesses and corporate strategies may be useful to leverage and sustain competitive advantage. Managers and supervisors may need more CSR education to understand how to blend institutional stakeholder requirements, strategy and core industry business.

Whilst this paper is limited by industry-level of analysis, future research could also explore this issue from the firm-level of analysis. Another useful extension of this research would be to assess the strategic nature of CSR practices in high-risk industries. Even more, future research could further explore institutional stakeholders' perspective on CSR practices in the high-risk industries. Exploring how managers' religious values and beliefs drive corporate philanthropy would not be a wasteful research venture.

\section{References}

Abor, J., \& Biekpe, N. (2007). Corporate governance, ownership structure and performance of SMEs in Ghana: Implications for financing opportunities. Corporate Governance: The International Journal of Business in Society, 7(3), 288-300. http://dx.doi.org/10.1108/14720700710756562

Abugre, J. B. (2014). Managerial role in organizational CSR: Empirical lessons from Ghana. Corporate Governance, 14(1), 104-119. http://dx.doi.org/10.1108/CG-10-2011-0076

Acciaro, M. (2012). Environmental social responsibility in shipping: Is it here to stay? The Quarterly Newsletter of the International Association of Maritime Economists.

Amaeshi, K. M., Adi, B. C., Ogbechie, C., \& Olufemi, O. A. (2006). Corporate social responsibility in Nigeria: Western mimicry or indigenous influences? Journal of Corporate Citizenship, 24, 83-99. 
http://dx.doi.org/10.9774/GLEAF.4700.2006.wi.00009

Amoako-Gyampah, K., \& Boye, S. S. (2001). Operations strategy in an emerging economy: The case of the Ghanaian manufacturing industry. Journal of Operations Management, 19, 59-79. http://dx.doi.org/10.1016/S0272-6963(00)00046-2

Amponsah-Tawiah, K., \& Dartey-Baah, K. (2011a). Corporate social responsibility in Ghana. International Journal of Business and Social Science, 2(17), 107-112.

Amponsah-Tawiah, K., \& Dartey-Baah, K. (2011b). Exploring the limits of western corporate social responsibility theories in Africa. International Journal of Business and Social Science, 2(18), 126-137.

Amran, A. B., \& Devi, S. S. (2007). Corporate social reporting in Malaysia: An institutional perspective. World Review of Entrepreneurship, Management and Sustainable Development, 3(1), 20-36. http://dx.doi.org/10.1504/WREMSD.2007.012128

Barsan, E., Surugiu, F., \& Dragomir, C. (2012). Factors of human resources competitiveness in maritime transport. International Journal on Marine Navigation and Safety of Sea Transportation, 6(1), 89-92. http://dx.doi.org/10.1201/b11345-9

Bazeley, P. (2007). Qualitative data analysis with NVivo. Los Angeles, CA: Sage Publications.

Berg, B. L., \& Lune, H. (2004). Qualitative research methods for the social sciences. Boston, USA: Pearson.

Brammer, S., Jackson, G., \& Matten, D. (2012). Corporate social responsibility and institutional theory: New perspectives on private governance. Socio-Economic Review, 10, 3-28. http://dx.doi.org/10.1093/ser/mwr030

Burnard, P. (2004). Writing a qualitative research report. Accident and Emergency Nursing, 12, 176-181. http://dx.doi.org/10.1016/j.aaen.2003.11.006

Campbell, J. L. (2007). Why would corporations behave in socially responsible ways? An institutional theory of corporate social responsibility. The Academy of Management Review, 32(3), 946-967. http://dx.doi.org/10.5465/AMR.2007.25275684

Carroll, A. B. (1991). The pyramid of corporate social responsibility: Toward the moral management of $\begin{array}{lllll}\text { organisational stakeholders. } & \text { Business } & \text { Horizons, } & 34(4), & 39-48 .\end{array}$ http://dx.doi.org/10.1016/0007-6813(91)90005-G

Creswell, J. W. (2007). Qualitative enquiry and research design: choosing among five approaches. Thousand Oaks, CA: Sage Publications.

Dashwood, H. S., \& Puplampu, B. B. (2010). Corporate social responsibility and Canadian mining companies in the developing world: the role of organizational leadership and learning. Canadian Journal of Development Studies / Revue canadienne d'études du développement, 30(1-2), 175-196.

Denzin, N., \& Lincoln, Y. (2005). The sage handbook of qualitative research. Thousand Oaks, CA: Sage Publications. http://dx.doi.org/10.1177/1468794105047237

Diller, J. (1999). A social conscience in the global marketplace? Labour dimensions of codes of conduct social labelling and investor initiatives. International Labour Review, 138(2), 99-129. http://dx.doi.org/10.1111/j.1564-913X.1999.tb00062.x

DiMaggio, P. J., \& Powell, W. W. (1983). The iron cage revisited: Institutional isomorphism and collective rationality in organizational fields. American Sociological Review, 48(2), 147-160. http://dx.doi.org/10.2307/2095101

Ellis, N., \& Sampson, H. (2013). Corporate social responsibility and the quality of Seafarers accommodation and recreational facilities. In IMISS 2013-proceedings of the international scientific meeting for corporate social responsibility (CSR) in shipping. 2nd International Maritime Incident and Near Miss Reporting Conference, 11-12 June 2013, Kotka, Finland.

European Commission Communication. (2004). On short sea shipping. Brussels.

Fafaliou, I., Lekakou, M., \& Theotokas, I. (2006). Is the European shipping industry aware of corporate social responsibility? The case of the Greek-owned short sea shipping companies. Marine Policy, 30(4), 412-441. http://dx.doi.org/10.1016/j.marpol.2005.03.003

Frazer, G. (2005). Which firms die? A look at manufacturing firm exit in Ghana. Economic Development and Cultural Change, 53(3), 585-617. http://dx.doi.org/10.1086/427246 
Ghana Maritime Authority. (2010). Annual report of the Ghana maritime authority. 2-48.

Ghana Shippers Council. (1997). Maritime trade statistics in Ghana. Accra, Ghana.

GIPC. (2012). Ghana investment promotion centre report. 4th Quarter Report. Accra, Ghana.

Halme, M., \& Laurila, J. (2009). Philanthropy, integration or innovation? Exploring the financial and societal outcomes of different types of corporate responsibility. Journal of Business Ethics, 84, 325-339. http://dx.doi.org/10.1007/s10551-008-9712-5

Havold, J. I., \& Nesset, E. (2009). From safety culture to safety orientation: Validation and simplification of a safety orientation scale using a sample of seafarers working for Norwegian ship owners. Safety Science, 47(3), 305-326. http://dx.doi.org/10.1016/j.ssci.2008.05.002

Heinze, D., Sibary, S., \& Sikula, S. A. (1999). Relations among corporate social responsibility, financial soundness, and investment value in 22 manufacturing industry groups. Ethics \& Behaviour, 9(4), 331-347. http://dx.doi.org/10.1207/s15327019eb0904_4

Hilson, G. (2012). Corporate social responsibility in the extractive industries: Experiences from developing countries. Resource Policy, 37, 131-137. http://dx.doi.org/10.1016/j.resourpol.2012.01.002

Hilson, G. M. (2007). What is wrong with the global support facility for small-scale mining? Progress in Development Studies, 7(3), 235-249. http://dx.doi.org/10.1177/146499340700700304

Hinson, R. E., Boateng, R., \& Madichie, N. (2010). Corporate social responsibility activity reportage on bank websites in Ghana. International Journal of Bank Marketing, 28(7), 498-518. http://dx.doi.org/10.1108/02652321011085176

Hinson, R. E. (2011). Online CSR reportage of award-winning versus non award-winning banks in Ghana. Journal of Information, Communication \& Ethics in Society, 9(2), 102-115. http://dx.doi.org/10.1108/14779961111148622

Hinson, R. E., \& Kodua, P. (2012). Examining the marketing-corporate social responsibility nexus. International Journal of Law and Management, 54(5), 332-344.

Horck, J. (2004). An analysis of decision-making processes in multicultural maritime scenarios. Maritime Policy and Management, 31(1), 15-29. http://dx.doi.org/10.1080/03088830310001642021

Huang, C., \& Kung, F. (2011). Environmental consciousness and intellectual capital management. Management Decision, 49(9), 1405-1425. http://dx.doi.org/10.1108/00251741111173916

Jackson, G. (2010). Actors and Institutions. In Morgan, G., Campbell, J., Crouch, C., Pedersen, O. K. and Whitley, R. (Eds.), The Oxford Handbook of Comparative Institutional Analysis (pp. 63-86). Oxford, Oxford University Press. http://dx.doi.org/10.1093/oxfordhb/9780199233762.003.0004

Jamali, D., \& Mirshak, R. (2007). Corporate social responsibility (CSR): Theory and practice in a developing country context. Journal of Business Ethics, 72, 243-262. http://dx.doi.org/10.1007/s10551-006-9168-4

Jamali, D., \& Neville, B. (2011). Convergence versus divergence of CSR in Developing Countries: An Embedded Multi-layered Institutional Lens. Journal of Business Ethics, 102, 599-621. http://dx.doi.org/10.1007/s10551-011-0830-0

Kuada, J., \& Hinson, R. E. (2012). Corporate social responsibility (CSR) practices of foreign and local companies in Ghana. Thunderbird International Business Review, 54(4), 521-535. http://dx.doi.org/10.1002/tie.21481

Lichtenstein, S., Badu, E., Owusu-Manu, D., Edwards, D. J., \& Holt, G. D. (2012). Corporate social responsibility architecture and project alignments: A study of the Ghanaian construction industry. Journal of Engineering, Design and Technology, 11(3), 334-353. http://dx.doi.org/10.1108/JEDT-09-2012-0041

Lu, C., \& Lin, C., \& Tu, C. (2009). Corporate social responsibility and organisational performance in container shipping. International Journal of Logistics Research and Applications: A Leading Journal of Supply Chain Management, 12(2), 119-132. http://dx.doi.org/10.1080/13675560902749373

Mahmoud, M. A., \& Hinson, R. E. (2012). Market orientation, innovation and corporate social responsibility practices in Ghana's telecommunication sector. Social Responsibility Journal, 8(3), 327-346. http://dx.doi.org/10.1108/17471111211247910

Matten, D., \& Moon, J. (2008). "Implicit" and "Explicit" CSR: A conceptual framework for a comparative understanding of corporate social responsibility. The Academy of Management Review, 33(2), 404-424. 
http://dx.doi.org/10.5465/AMR.2008.31193458

Mayring, P. (2003). Qualitative Inhaltsanalyse, Grundlagen und Techniken. Weinheim: Beltz, UTB.

McSweeney, K., Craig, B., \& Tomlinson, C. (2013). Using safety performance metrics to support CSR goals and objectives. In IMISS 2013-proceedings of the international scientific meeting for corporate social responsibility (CSR) in shipping. 2nd International Maritime Incident and Near Miss Reporting Conference, 11-12 June 2013, Kotka, Finland.

Metaxas, T., \& Tsavdaridou, M. (2012). Corporate social responsibility (CSR) on metallurgy sector in Greece. Retrieved on 20 January 2015 from http://mpra.ub.uni-muenchen.de/42789/

Miles, M., \& Huberman, A. M. (1984). Qualitative data analysis. Beverly Hills, CA: Sage Publication.

Ofori, D. F., \& Hinson, R. E. (2007b). Corporate social responsibility (CSR) perspectives of leading firms in Ghana. Corporate Governance, 7(2), 178-193. http://dx.doi.org/10.1108/14720700710739813

Okun, A., Lentz, T. J., Schulte, P., \& Stayner, L. (2001). Identifying high-risk small business industries for occupational safety and health interventions. American Journal of Industrial Medicine, 39(3), 301-311. http://dx.doi.org/10.1002/1097-0274(200103)39:3<301::AID-AJIM1018>3.0.CO;2-L

Panwar, R., \& Hansen, E. N. (2009). Process for identifying social and environmental issues: A case of the US forestry products manufacturing. Journal of Public Affairs, 9, 323-336. http://dx.doi.org/10.1002/pa.336

Pedersen, E. R. (2010). Modelling CSR: how managers understand the responsibilities of business towards society. Journal of Business Ethics, 91, 155-166. http://dx.doi.org/10.1007/s10551-009-0078-0

Pedersen, P. O. (2001). Freight transport under globalisation and its impact on Africa. Journal of Transport Geography, 9, 85-99. http://dx.doi.org/10.1016/S0966-6923(01)00006-0

Pedersen, P. O. (2003). Development of freight transport and logistics in Sub-Saharan Africa: Taaffe, Morrill and Gould revisited. Transport Reviews: A Transnational Transdisciplinary Journal, 23(3), 275-297. http://dx.doi.org/10.1080/0144164032000091681

Poulovassilis, A., \& Meidanis, S. (2013). Sustainability of shipping-addressing corporate social responsibility through management systems. Retrieved on 2nd August, 2014 from http://www.commonlawgic.org/sustainability-of-shipping.html

Quartey, S. H., \& Puplampu, B. B. (2012). Employee health and safety practices: An exploratory and comparative study of the shipping and manufacturing industries in Ghana. International Journal of Business and Management, 7(23), 81-95. http://dx.doi.org/10.5539/ijbm.v7n23p81

Reason, J. (1997). Managing the risks of organizational accidents. Aldenhot: Ashgate.

Roe, M. (2008a). Safety, security, the environment and shipping-The problem of making effective policies. WMU Journal of Maritime Affairs, 7(1), 263-279. http://dx.doi.org/10.1007/BF03195135

Scott, W. R. (1995). Institutions and organizations. Sage, Thousand Oaks, CA: Sage Publications.

Scott, W. R. (2001). Institutions and organizations. Sage, Thousand Oaks, CA: Sage Publications.

Selkou, E., \& Roe, M. S. (2004). Globalization, policy and shipping. Cheltenham: Edward Elgar.

Soderbom, M., \& Teal, F. (2004). Size and efficiency in African manufacturing firms: Evidence from firm-level $\begin{array}{lllll}\text { panel data. Journal of Development } & \text { Economics, } & 73, & 369-394 .\end{array}$ http://dx.doi.org/10.1016/j.jdeveco.2003.02.005

Steiner, G., \& Steiner, J. (2000). Business, government and society: A managerial perspective. Boston, MA: McGraw-Hill.

Sutton, J., \& Kpentey, B. (2012). An enterprise map of Ghana. International Growth Centre, London: UK.

Torugsa, N. A., O’Donohue, W., \& Hecker, R. (2012). Capabilities, proactive CSR and financial performance in SMEs: Empirical evidence from an Australian manufacturing industry sector. Journal of Business Ethics, 109, 483-500. http://dx.doi.org/10.1007/s10551-011-1141-1

Waddock, S. E., \& Graves, S. B. (1997). The corporate social performance-financial performance link. Strategic Management Journal, 303-319. http://dx.doi.org/10.1002/(SICI)1097-0266(199704)18:4<303::AID-SMJ869>3.0.CO;2-G

Wartick, S. L., \& Wood, D. J. (1998). International Business and Society. Malden: Blackwell Publishers. 
Williamson, D., Lynch-Wood, G., \& Ramsay, J. (2006). Drivers of environmental behaviour in manufacturing SMEs and the implications for CSR. Journal of Business Ethics, 67, 317-330. http://dx.doi.org/10.1007/s10551-006-9187-1

Yankson, P. W. K. (2010). Gold mining and corporate social responsibility in the Wassa West district, Ghana. Development in Practice, 20(3), 354-366. http://dx.doi.org/10.1080/09614521003709965

$\mathrm{Yu}, \mathrm{X}$. (2008). Impacts of corporate code of conduct on labor standards: a case study of reebok's athletic footwear supplier factory in China. Journal of Business Ethics, 81, 513-529. http://dx.doi.org/10.1007/s10551-007-9521-2.

\section{Copyrights}

Copyright for this article is retained by the author(s), with first publication rights granted to the journal.

This is an open-access article distributed under the terms and conditions of the Creative Commons Attribution license (http://creativecommons.org/licenses/by/3.0/). 